\title{
Pemanfaatan Teknologi Digital Sebagai Usaha Meningkatkan Kemampuan Kreatif Pekerja Desain di Ikm Alas Kaki Melalui Kegiatan Perancangan Ragam Hias Upper Sepatu
}

\author{
Mohamad Arif Waskito ${ }^{1}$ \\ Edi Setiadi Putra2 \\ 1,2Jurusan Desain Produk, \\ Institut Teknologi Nasional (ITENAS) \\ Jl. PHH Mustapha 23, Bandung - INDONESIA \\ 1mawaskito@itenas.ac.id
}

\begin{abstract}
Abstrak
Pemanfaatan teknologi digital dan informatika di dunia industri memiliki peran penting pada bidang perancangan, produksi, distribusi hingga pemasaran sehingga mampu menggantikan cara-cara konvensional yang selama ini diterapkan. Perkembangan teknologi digital di dunia industri membuat Indonesia berusaha untuk menjadi negara industri maju melalui pencanangan Revolusi Industri Indonesia 4.0 sebagai konsep pembangunan industrinya (Kemenperin RI, 2018). Namun percepatan penggunaan teknologi digital tersebut belum sepenuhnya mampu diikuti oleh kelas industri kecilmenengah (IKM), yang salah satu penyebabnya adalah sumber daya manusia (SDM) di industri yang masih gagap terhadap adanya kemajuan tersebut.
\end{abstract}

Di industri kecil alas kaki, teknologi digital dapat diterapkan pada kegiatan perancangan produk atau pembuatan ornamen ragam hias pada upper. Hanya saja untuk dapat diimplementasikan sebagai proses kreasi, diperlukan strategi khusus mengingat SDM yang berperan sebagai tenaga kerja bidang desain di IKM-IKM umumnya tidak memiliki pendidikan formal dan pada umumnya terbiasa dengan tindakan peniruan atau memodifikasi yang mengakibatkan rendahnya kemampuan kreativitas mereka.

Merujuk pada kondisi seperti itu, maka dikembangkan teknik modifikasi digital (Digital Modification Technique/ DMT) yang merupakan teknik menyederhanakan bentuk dari suatu objek tertentu (stilasi) dengan melibatkan software aplikasi desain untuk menghasilkan kreasi-kreasi baru dalam bentuk ragam hias, yang kemudian dijadikan ornamen visual pada bagian upper sepatu. Melalui teknik sederhana ini diharapkan para pengrajin dapat mempelajarinya dengan mudah sehingga lebih produktif dan kreatif untuk menghasilkan kebaruan dan keunikan pada produk-produk yang mereka hasilkan.

Kata kunci: IKM alas kaki, Digital Modification Techniques/DMT, kreatif, kebaruan dan keunikan desain

\begin{abstract}
The use of digital technology and informatics in the industrial world has an important role in the fields of design, production, distribution and marketing so as to replace conventional methods that have been implemented. The development of digital technology in the industrial world has made Indonesia strive to become an advanced industrial country through the launch of the Indonesian Industrial Revolution 4.0 as the concept of its industrial development (Ministry of Industry, 2018). However, the acceleration of the use of digital technology has not been fully able to be followed by Small-Medium Industry (SMI) classes, one of the causes of which is human resources (HR) in the industry who are still stuttering about the progress.

In the small footwear industry, digital technology can be applied to product design activities or the making of decorative ornaments in the upper. It's just that to be implemented as a creative process, a special strategy is needed considering that human resources who act as design workers in the SMI generally do not have formal education and are generally accustomed to imitation or modifying actions that result in their low creativity.

Referring to such conditions, a digital modification technique (DMT) is developed which is a technique to simplify the form of a particular object by involving design application software to produce new creations in the form of ornament, which is then used as an ornament visually on the upper part of the shoe.
\end{abstract}
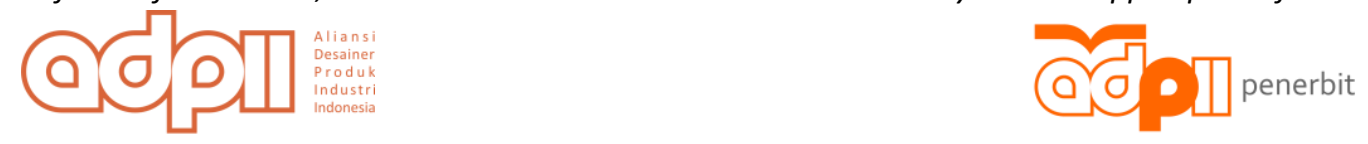
Through this simple technique, it is expected that the craftsmen can learn it easily so that it is more productive and creative to produce novelty and uniqueness in the products they produce.

Keywords: Footwear small industries, Digital Modification Techniques / DMT, creative, novelty and unique design

\section{PENDAHULUAN}

Kebijakan pembangunan industri Indonesia yang berbasis pada konsep padat karya dengan mengandalkan tenaga kerja murah dan sumber alam melimpah sudah selayaknya dialihkan menjadi konsep padat modal yang mengutamakan SDM berkualitas dan pemanfaatan teknologi-teknologi mutakhir. Pemanfaatan teknologi digital diharapkan dapat memacu produktivitas dan daya saing bagi industri kecil dan menengah (IKM) sehingga mampu menembus pasar ekspor [1]. Peranan teknologi dalam industri menjadi kebutuhan yang cukup vital dalam mengimbangi percepatan kebutuhan dan persaingan pasar pada saat ini. Konsep keunggulan komparatif sekarang diganti dengan konsep keunggulan kompetitif yang bersifat padat modal dan menerapkan teknologi tinggi [2]. Keunggulan upah tenaga kerja murah di Indonesia selalu dikomparasi dengan upah tenaga kerja negara-negara berkembang lainnya untuk menarik investasi asing, tapi pada saat ini keunggulan tersebut sudah tidak dapat lagi diandalkan. Kebijakan Indonesia dalam menarik investasi asing akan lebih mengarah pada pemanfaatan teknologi dan sumber daya manusia berkualitas malalui kebijakan Revolusi Industri Indonesia 4.0. Pencanangan Indonesia masuk pada era revolusi tahap empat ini akan mempengaruhi sistem dan kultur kerja di industri, termasuk di IKM yang selama ini sangat bergantung pada konsep padat karya dengan tenaga kerja murah. Perlu ada penyesuaian kemampuan tenaga kerja agar terbiasa menghadapi kondisi percepatan pembangunan industri yang menggunakan teknologi digital dan teknologi informatika sebagai tulang punggungnya.

Di industri kecil-menengah sektor alas kaki teknologi digital belum banyak dilibatkan karena SDM yang dimiliki masih belum memiliki pengetahuan, kemampuan dan pemahaman yang baik terhadap teknologi-teknologi digital tersebut. Selain itu kehadiran teknologi digital belum memiliki kesempatan untuk masuk dan diimplementasi dalam sistem produksi yang biasa dilakukan, hal ini karena sebagian besar IKM merupakan industri berbasis "produksi". Sedangkan teknologi digital yang memiliki karakter hasil kerja berupa percepatan, orisinalitas kreasi dan produkstifitas tinggi akan lebih mudah diadopsi oleh industri-industri yang berbasis pada "kreativitas". Namun keberadaan teknologi digital telah menjadi keniscahyaan dan tidak dapat dipungkiri bahwa kemajuan teknologi telah mampu meningkatkan produktivitas dan keunggulan industri baik yang berbasis produksi maupun indutri yang berbasis kreativitas. Di Industri/ usaha kecil dan menengah (UKM) yang telah memberlakukan teknologi digital menunjukkan pertumbuhan yang lebih cepat dari perusahaan yang belum memberlakukannya [2]. Pada artikel tersebut juga diungkap bahwa antara 52,5\% dan 60,2\% dari UKM yang disurvei mengklaim bahwa solusi teknologi baru telah memungkinkan mereka untuk memulai atau melanjutkan merevisi alur kerja dan proses untuk merampingkan operasi dan meningkatkan produktivitas.

Pengunaan perangkat komputer pada mesin-mesin produksi di industri (computerized machine) sudah banyak dilibatkan untuk mendukung kerja operasinya agar lebih efektif, otomatis, dan berstandarisasi. Termasuk pada bidang kerja perancangan atau desain, penggunaan perangkat komputer, media digital dan teknologi informatika sudah menjadi perangkat pendukung yang mampu meningkatkan produktifitas di industri. Proses kreasi yang dilakukan oleh para perancang dengan melibatkan teknologi digital dapat dihasilkan dan dikembangkan dengan cepat, tanpa mengurangi kualitas orisinalitasnya. Para arsitek atau desainer umumnya beradu dalam hal kreativitas dan keunikan dalam menciptakan karya yang menarik, artistik dan sesuai kebutuhan klien [4]. Semua orang dapat menemukan sesuatu (yang baru), yang sesuai dengan selera pribadi, karakter individu dan minatnya [5]. Dengan demikian keberadaan teknologi digital sebagai "perangkat kreasi" akan memberikan peluang penemuanpenemuan baru dalam bentuk karya desain di tangan para tenaga kerja bidang desain di industriindustri yang berbasis kreativitas.

Namun seperti yang diketahui bahwa proses kreasi membutuhkan dukungan kemampuan, keterampilan dan pemahaman dasar estetika yang biasanya didapatkan melalui pendidikan-pendidikan formal. Sedangkan pada kenyataannya para pelaku IKM umumnya tidak memiliki kualifikasi profesional,
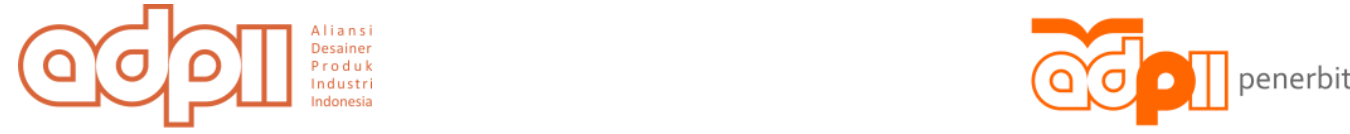
sehingga kemampuan kognisi para pelaku IKM tersebut sering kali menjadi penghambat pengembangan gagasan dan kreasi karyanya. Pengembangan sistem CAD (Computer Aided Design) dan pemanfaatannya harus dilakukan berdasarkan pemahaman yang mendalam tentang proses kognitif desainer [6]. Melihat faktor pendidikan formal yang menjadi penghambat berkembang kemampuan kreasi para pelaku IKM tersebut, telah memberikan peluang untuk mengembangkan strategi-strategi tertentu agar kemampuan kreasi mereka dapat diimplementasikan pada kegiatan perancangan produk di industrinya.

\section{METODE DAN DATA}

\subsection{Konsep pengambangan desain di IKM batik tulis}

Penguasaan teknologi digital yang diterapkan pada proses kreasi di industri kecil-menengah membutuhkan metode yang efektif mengingat kemampuan dan kapabilitas kreasi tenaga perancang yang ada di industri tersebut umumnya masih terbatas. Pengaruh perilaku dan kultur kerja yang terbiasa dengan tindakan meniru dan memodifikasi membuat mereka sulit untuk berkreasi, apalagi berimajinasi sebagai syarat dasar proses penciptaan objek-objek baru yang bernilai inovasi. Oleh karena itu dengan memanfaatkan software digital yang populer digunakan oleh masyarakat, kemudian dikembangkan teknik modifikasi objek yang berbasis pada teknik stilasi (penyederhanaan bentuk). Penggunaan teknik stilasi melalui proses tracing objek (penelusuran bentuk objek) adalah kegiatan yang paling sederhana dilakukan, sehingga para pengrajin tidak akan mengalami kesulitan yang berarti untuk mempelajarinya. Metode replikasi dan modifikasi ini diadopsi dari proses kreasi yang dilakukan di IKM batik tulis, dan sampai sejauh ini metode tersebut efektif untuk menghasilkan modul-modul ragam hias yang menjadi elemen desain dari produk yang dihasilkan oleh industri tersebut. Proses kreasi pembentukan ragam hias dimulai dengan mendokumentasi objek-objek gambar menjadi data visual dalam bentuk Clip Art Library yang kemudian dikembangkan melalui metode modifikasi seperti proses scaling, mirror, flip dan lainnya disamping penentuan proposi dan komposisi gambar [7]. Hasil dari kegiatan stilasi objek, replikasi dan modifikasi dalam bentuk modul ragam hias kemudian dikembangkan melalui pengaturan rana (penguasaan bidang) dan proporsi objek untuk diletakkan pada bidang dari media yang telah direncanakan, yang pada IKM batik tulis berupa lembaran kain dan jika di IKM alas kaki dalam bentuk potongan pola upper.

Kegiatan kreasi di IKM batik tulis dengan menggunakan teknik modifikasi digital dapat digambarkan dalam skema seperti di bawah ini:

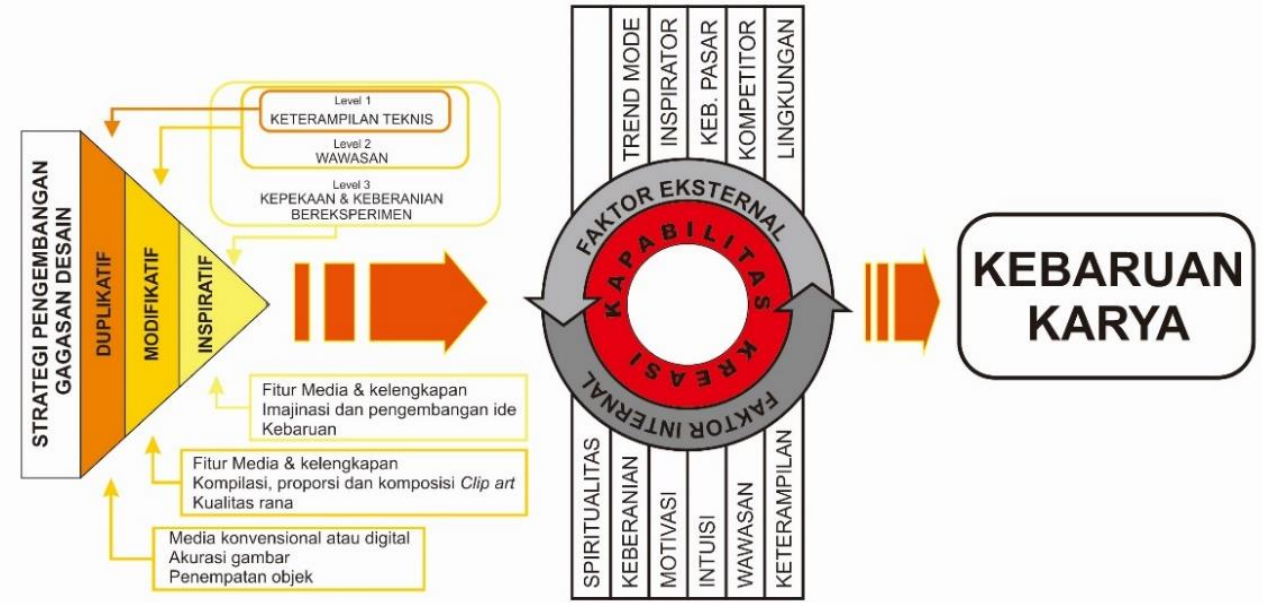

Gambar 1. Skema Pengembangan Kreasi di IKM batik tulis

Di lingkungan IKM batik tulis, strategi pengembangan gagasan desain dikelompokkan dalam 3 katagori penanganan yaitu duplikasi, modifikasi dan inspirasi. Penanganan paling mudah dan merupakan usaha paling sederhana yang dapat dilakukan oleh tenaga desain IKM adalah meniru, mendupilkasi atau replikasi objek. Tindakan ini hanya menuntut keterampilan teknis dengan ketepatan dan akurasi bentuk
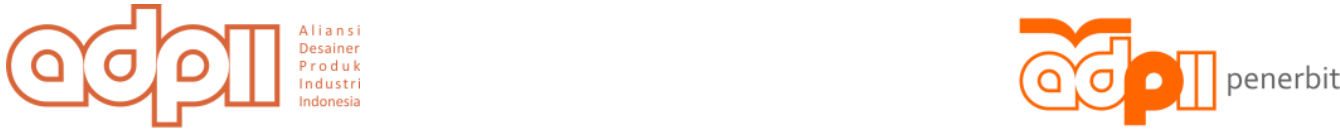
dari objek yang ditirunya. Sedangkan modifikasi merupakan kegiatan peniruan objek yang disertai perubahan kecil (minor change) dari sebagian objek tersebut. Tindakan modifikasi tidak hanya membutuhkan kemampuan teknis saja, akan tetapi juga membutuhkan wawasan visual agar dapat mengkomparasikannya dengan objek-objek yang sejenis sehingga pada karya yang dihasilkannya akan ditemukan perubahan berupa kebaruan-kebaruan bentuk. Tindakan kreasi yang paling sulit dilakukan oleh pengrajin yaitu kegiatan perancangan yang didasari dari gagasan yang berbentuk inspirasi. Karyakarya desain yang gagasan awalnya berdasar dari sebuah situasi atau kondisi tertentu merupakan wujud usaha mendeskripsikannya dalam bentuk objek visual. Di IKM batik tulis, ketiga tindakan tersebut telah biasa dilakukan yang masing-masing tindakan kreasi tersebut akan mempengaruhi kualitas desain dan tema ragam hias dari produk-produk yang dihasilkannya.

\subsection{Proses desain pada produk batik tradisional}

Ragam hias atau motif pada batik yang ada di masyarakat Indonesia memiliki latar belakang penciptaan yang berbeda-beda. Masing-masing motif hadir ditengah masyarakat dipengaruhi oleh filosofi kehidupan yang berkembang pada saat itu sehingga motif-motif tersebut dapat menginterpretasikan karakteristik kehidupan mereka. Namun pada perkembangannya, motif batik sebagaian besar telah menjadi komoditi ekonomi yang keberadaannya sudah tidak lagi didasari atas tata aturan dan batasan pemakaian. Karya-karya tradisi yang sudah memasyarakat dalam waktu yang cukup lama berdasarkan tata perundang-undangan yang berlaku di Indonesia telah bergeser menjadi karya yang keberadaannya dapat dimanfaatkan secara ekonomi oleh warga negara Indonesia secara bebas. Karya batik tradisional seperti Parang Rusak, Sidomukti, Truntum dan lain-lain menurut perhitungan panjang waktu perlindungan hak ciptanya telah berakhir dan menjadi public domain. Karena itu bagi orang Indonesia sendiri pada dasarnya bebas untuk menggunakannya [8]. Dengan demikian motif-motif batik tersebut walaupun dulunya termasuk kedalam jenis batik larangan, pada saat ini diperkenankan untuk direplikasi oleh masyarakat luas dan diaplikasikan pada beragam produk pakai lainnya.

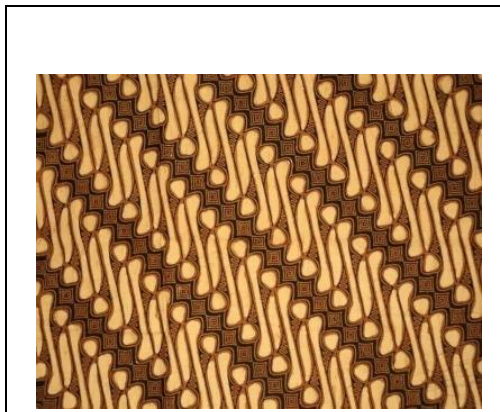

Sumber Gbr:

http://indonesianbatik.id/2018/03/16/ba

tik-tulis-motif-parang-rusak-motifmahakarya-hasil-bertapa-panembahansenopati/

Terinspirasi dari tebing-tebing karang atau pereng yang rusak karena terkikis deburan ombak laut selatan Batik Parang Rusak yang dulu termasuk batik larangan yang pemakaiannya terbatas dalam keraton saja. Sekarang sudah menjadi motif public domain sehingga bentuknya dapat direplikasi secara bebas oleh masyarakat
Page | 18

Gambar 2. Beberapa contoh batik tradisional dan latar belakang penciptaannya

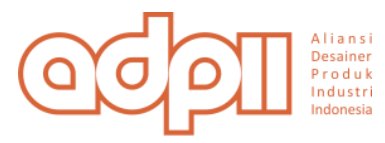

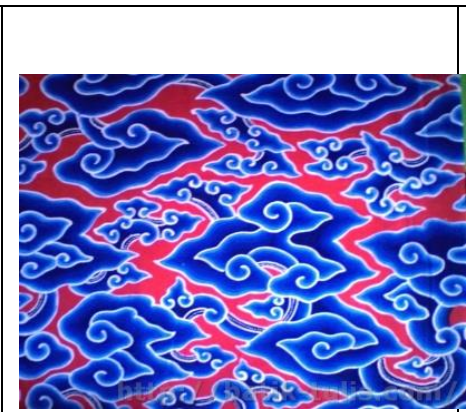

Sumber Gbr:

https://batik-tulis.com/blog/batikmega-mendung/

Batik Mega Mendung menurut sejarahnya dipengaruhi oleh motif awan Tiongkok yang kemudian oleh masyarakat Cirebon dimodifikasi sesuai dengan situasi/ kondisi sosial dan spiritual pada saat itu.

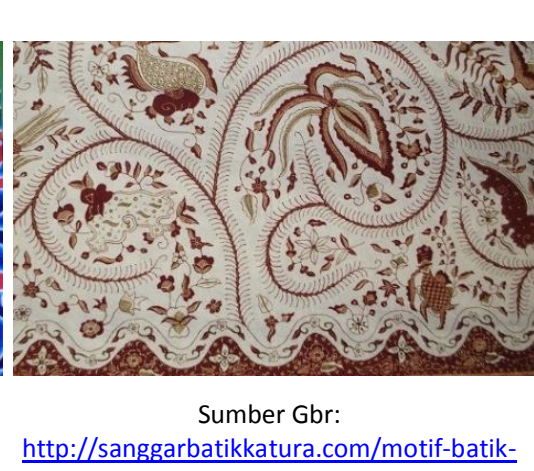
pesisiran-ganggeng

Batik Ganggeng merupakan salah satu motif batik pesisir masyarakat Cirebon yang pada proses penciptaannya didasari dari inspirasi objek-objek flora dan fauna yang ditemui di pasisir pantai Cirebon 
Motif batik Keraton Cirebon memiliki makna simbolik dan filosofis yang mengandung pesan moral. Ide dasar batik keraton adalah dari ragam hias Keraton Cirebon, naskah dan mushaf Al-qur'an pada Abad 2OInvalid source specified.. Pada motif Mega Mendung menurut sejarahnya mengarah pada satu sejarah akan kedatangan bangsa China ke wilayah Cirebon yang pada akhirnya merujuk pada pernikahan Sunan Gunung Jati dengan ratu Ong Tien pada abad ke-16. Kemudian rakyat cirebon mengenal beberapa benda seni China seperti piring, keramik, dan kain yang memiliki motif bentuk awan [9]. Ornamen motif awan tersebut kemudian dimodifikasi dan dikembangkan sesuai dengan kondisi sosial dan spiritual yang berkembang pada saat itu sehingga hasil dari modifikasi tersebut memunculkan nilai kebaruan bentuk yang bersifat orisinal sebagai pembeda dengan motif awan asalnya. Motif batik Cirebon Mega Mendung memiliki ciri khas yaitu bentuk garis-garis awan yang berbentuk lonjong, lancip dan segitiga yang berbeda dengan garis awan motif China yang umumnya berbentuk bulatan [10]. Sedangkan menurut budayawan Cirebon Elang Hilman, menyatakan bahwa bedanya Mega Mendung dengan motif awan milik Tionghoa cuma gradasi. Motif awan milik China tidak ada gradasi warna [11]. Dengan demikian pada saat ini kita dapat mengenali secara jelas keunikan dan perbedaan antara motif awan masyarakat Tiongkok dengan motif awan pada batik Mega Mendung. Proses penciptaan batik Mega Mendung dapat menjadi contoh kasus yang menunjukkan bahwa teknik modifikasi sebagai sebuah tindakan deskripsi visual dengan melibatkan kemampuan kreatif dapat memberikan peluang untuk menghasilkan bentukbentuk baru yang nilai orisinalitasnya cukup baik dan dapat dihargai sebagai usaha yang otentik.

\subsection{Pemetaan kapabilitas tenaga kreatif di lingkungan industri kecil}

Di IKM batik tulis yang menjadi sumber referensi, keberadaan tenaga-tenaga kreatif yang menjadi bagian dari proses kreasi biasanya akan didukung oleh tenaga-tenaga terdidik berdasarkan tingkat kemampuan tertentu sesuai dengan tugas dan wewenangnya. Proses pengembangan desain di industri merupakan proses transformasi gagasan ke dalam wujud objek desain yang direalisasikan oleh individu yang memiliki level keahlian tertentu [7]. Peningkatan kemampuan tersebut biasanya dilakukan secara berkala dan berkesinambungan berdasarkan tingkat (level) yang dimiliki dan usaha untuk meningkatkan kemampuan kreasi tersebut dapat ditingkatkan dalam kurun waktu 2-3 bulan. Kualifikasi kemampuan kreasi para tenaga pelaksana desain yang ada di IKM dapat diklasifikasikan sebagai berikut:

Tabel 1. Proporsi tenaga desain di IKM Batik Tulis Komar

\begin{tabular}{|c|c|c|}
\hline $\begin{array}{l}\text { Tingkat } \\
\text { keterampilan }\end{array}$ & Deskripsi keahlian & $\begin{array}{lr}\text { Proporsi } & \text { tenaga } \\
\text { kreatif } & \text { dalam } \\
\text { industri } & \end{array}$ \\
\hline $\begin{array}{l}\text { Level } \\
\text { (pelaksana } \\
\text { teknis } \\
\text { duplikasi) }\end{array}$ & $\begin{array}{l}\text { Kemampuan menjiplak/ meniru bentuk modul gambar dari objek } \\
\text { tertentu } \\
\text { Keterampilan mengoperasikan fitur program digital dasar (membentuk } \\
\text { garis, bidang, kurva tidak beraturan, tracing, copy object) }\end{array}$ & $10 \%$ \\
\hline $\begin{array}{l}\text { Level } 2 \\
\text { (Pelaksana } \\
\text { teknis dan } \\
\text { pengembang } \\
\text { visualisasi } \\
\text { gagasan) }\end{array}$ & $\begin{array}{l}\text { Kemampuan dasar seperti pada Level } 1 \\
\text { Kemampuan membangun komposisi/ tata letak modul pada bidang yang } \\
\text { telah ditentukan } \\
\text { Kemampuan memodifikasi modul gambar (flip, scaling, rotate, \& stretch) } \\
\text { Keterampilan mengoperasikan fitur program digital untuk mendapatkan } \\
\text { modul-modul clip art baru }\end{array}$ & $60 \%$ \\
\hline $\begin{array}{l}\text { Level } 3 \\
\text { (Konseptor } \\
\text { dan } \\
\text { pengembang } \\
\text { gagasan) }\end{array}$ & $\begin{array}{l}\text { Kemampuan pengembangan modul gambar seperti pada level } 1 \\
\text { Memiliki imajinasi kreasi untuk menghasilkan modul gambar baru tanpa } \\
\text { proses menjiplak atau meniru dari objek tertentu } \\
\text { Membangun komposisi modul-modul gambar baru pada sebuah bidang } \\
\text { gambar tertentu }\end{array}$ & $30 \%$ \\
\hline
\end{tabular}

Sumber: wawancara dengan IKM Batik Tulis Komar
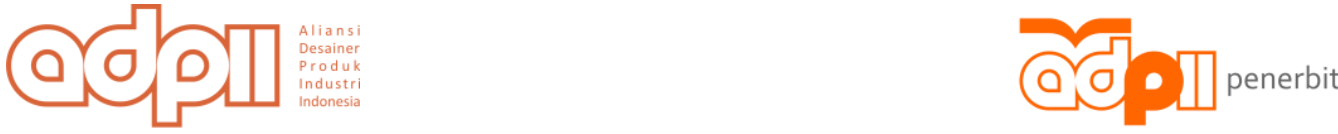
Proses kreatif yang dilakukan oleh tenaga bidang desain dengan kualifikasi level 1 umumnya menangani pekerjaan yang tidak menuntut kreativitas. Di IKM batik tersebut, kegiatan yang ditangani oleh tenaga dengan kualifikasi level 1 biasanya meliputi pekerjaan duplikasi modul gambar, tracing motif dan nyorek/mola. Alokasi tenaga kerja desain yang paling banyak (60\%) ada pada level 2 yang memiliki kualifikasi baik dalam keterampilan teknis dan mampu menggunakan daya kreativitasnya dalam memvisualisasikan gagasan-gagasan untuk membuat modul desain baru. Sedangkan tenaga-tenaga desain yang berkualifikasi level 3 memiliki tanggung jawab sebagai konseptor desain dengan ruang lingkup pekerjaan antara lain menetapkan tema desain yang akan diproduksi, membuat konsep bentuk dan desain modul ragam hias, dan menyempurnakan desain secara keseluruhan karena di level ini seseorang harus mampu selain memiliki keterampilan teknis, juga memiliki daya kreatif yang baik sehingga imajinasi dan ide-ide inspiratifnya dapat dijadikan dasar pembentukan dan penemuan desain yang bersifat orisinal. Proporsi tenaga level 3 ini dapat mencapai 30\% dari keseluruhan pekerja bidang desain, biasanya dibentuk dalam sebuah tim desain yang terdiri dari pemilik (owner) dan beberapa orang desainer yang ditugasi sebagai konseptor. Besaran prosentase proporsi tenaga desain disetiap level akan bergantung pada jenis industrinya. Industri yang berbasis produksi, prosentase tenaga desain akan lebih sedikit karena perusahaan akan fokus pada efektifitas dan efisiensi produksi. Tapi untuk perusahaan atau industri yang berbasis kreativitas, maka tenaga kerja bidang desainnya akan lebih banyak karena target yang diharapkan adalah keunggulan-keunggulan desain dalam bentuk desain yang unik dan orisinal.

\subsection{Teknologi digital dalam pengembangan kreasi desain}

Merujuk pada hasil penelusuran kemampuan kreatif yang dimiliki oleh para pelaku IKM sektor alas kaki di wilayah Cibaduyut, didapat data $69 \%$ pengrajin masih belum mampu menemukan kebaruan saat melakukan kegiatan perancangan. Sekitar $25 \%$ responden sudah dapat menunjukkan adanya kebaruankebaruan bentuk walaupun masih bersifat minor (minor change), sedangkan sekitar 6\% responden dapat dianggap mampu menghasilkan keunikan dan kebaruan-kebaruan (novelty) yang didapat dari penggalian sebuah inspirasi [12]. Tingginya populasi pelaku IKM yang tidak memiliki kemampuan untuk menemukan kebaruan saat berkreasi umumnya dikarenakan rendahnya keterampilan teknis dalam memvisualisasi gagasan dan kultur lingkungan kerja yang tidak memberikan peluang mereka untuk merealisasikan imajinasinya. Sedangkan keterampilan teknis berdasarkan observasi di IKM Batik Tulis Komar menunjukkan bahwa kemampuan meduplikasi dan memodifikasi masih memungkinkan dipelajari oleh para tenaga desain pada level 1 dan 2, walaupun mereka tidak memiliki latarbelakang pendidikan desain secara formal. Proses duplikasi dan modifikasi objek dapat dipelajari dengan mudah dengan bantuan teknologi digital. Teknologi digital telah memungkinkan sebuah objek dapat ditiru melalui teknik tracing dan di-stilasi (disajikan dengan bentuk lebih sederhana) oleh fitur-fitur operasi yang sudah terdapat pada beragam program aplikasi desain seperti Corel Draw (C), Adobe PhotoShop (C), Adobe Illustrator(C) dan lain-lain.

Dengan bantuan teknologi tersebut, pengrajin dapat memaksimalkan ide yang terbangun saat berkreasi dalam sebuah ruang virtual sebagai simulasi hasil kerja sebelum merealisasikannya dalam kegiatan produksi. Teknologi digital mengarah pada penciptaan dunia baru, 'realitas berbeda' yang sering kita sebut 'ruang virtual' atau 'lingkungan virtual' (VE). Perkembangan teknologi, yang memungkinkan manusia masuk ke dalamnya untuk menjadi semakin sempurna. Hampir semua yang bisa dibayangkan dapat dimodelkan di dalam lingkungan virtual: seseorang dapat 'hidup' dan 'melakukan sesuatu' di sana, yaitu seseorang dapat mensimulasikan semua jenis aktivitas manusia [5]. Ruang visual yang disediakan oleh teknologi digital melalui software-software aplikasi akan membantu para pekerja desain untuk dapat mensimulasikan gagasan-gagasan mereka sebelum direalisasikan sebagai karya. Software aplikasi desain tersebut telah mampu menjembatani gagasan-gagasan yang bersifat imajiner ke dalam bentukbentuk visual yang bersifat riil sehingga kreasi yang diciptakan dapat memberikan kebaruan tertentu yang nilainya menjadi bagian dari keunggulan suatu produk.

\section{HASIL DAN PEMBAHASAN}

Proses kreasi yang dilakukan oleh para tenaga desain yang ada di industri kecil membutuhkan dukungan teknologi digital untuk mendapatkan hasil kerja dengan kecepatan, akurasi dan orisinalitas tinggi. Aspek internal berupa ketrampilan, pengetahuan, pemahaman dan kepekaan terhadap aspek-aspek desain pada sebuah kegiatan perancangan harus didukung oleh perangkat dan kemampuan operasi media yang
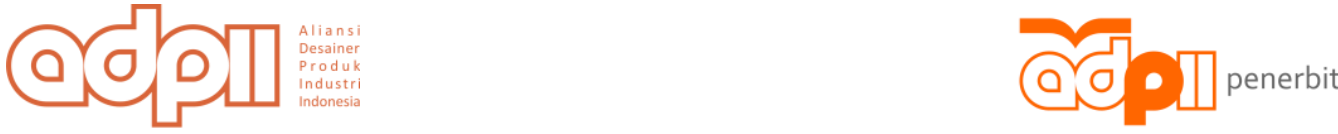


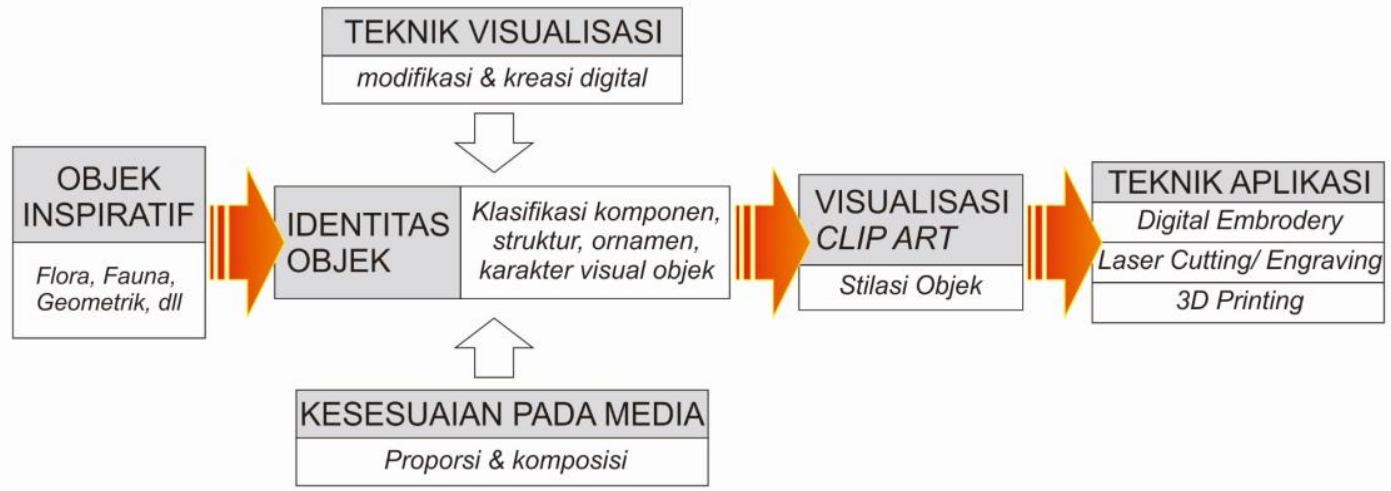

Gambar 3. Skema proses pembentukan modul desain ragam hias

berbasis teknologi digital. Teknologi digital akan meningkatkan percepatan produktivitas karena mampu mengeliminir hambatan-hambatan teknis seperti keterampilan menggambar atau memvisualisasikan gagasan.

Pada proses perancangan yang dilakukan di IKM alas kaki, kegiatan membuat motif ragam hias pada bagian upper sepatu dapat dilakukan dengan menggunakan Teknik Modifikasi Digital (Digital Modification Techniques/DMT). Metode ini dinilai sangat memungkinkan untuk dipelajari oleh para pekerja desain level 1 dan 2 karena selain tindakan modifikasi sudah biasa dilakukan, penggunaan software aplikasi digital pun mudah untuk dipelajari dan tidak menuntut keahlian tinggi untuk dapat mengoperasikannya. Keunggulan pembuatan modul desain dalam bentuk digital memungkinkannya untuk dimodifikasi dengan beragam operasi (flip, mirror, strech, array, dII) sehingga dapat menghasilkan

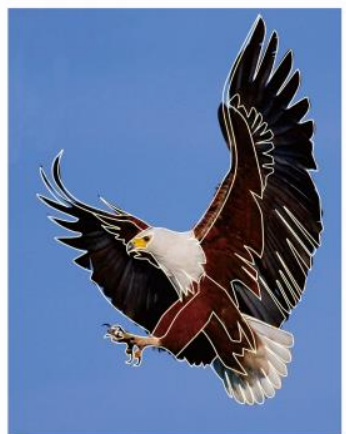

Step 1:

Tracing objek dengan

teknik stilasi

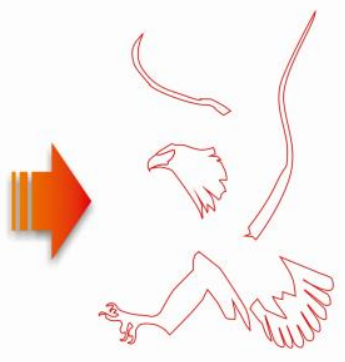

Step 2:

Penetapan bagian-bagian utama yang menjadi "jangkar bentuk" sebagai identitas melalui teknik modifikasi dan stilasi
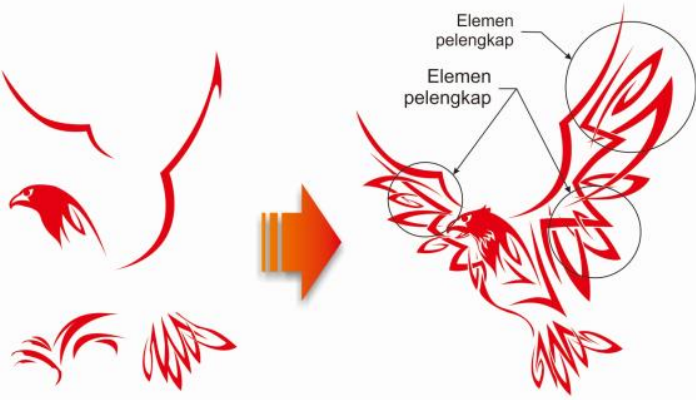

Step 3:

Melengkapi modul ragam hias, dengan elemen-elemen pelengkap yang berfungsi sebagai penguat bentuk

\section{Gambar 4. Proses pembentukan modul ragam hias}

beragam varian desain yang pada teknik konvensional biasanya memakan waktu lebih lama. Inspirasi atau gagasan pembuatan modul-modul desain dapat menggunakan bentuk objek-objek artifisial atau objek natural. Objek-objek inspiratif tersebut biasanya memiliki kompleksitas bentuk yang tinggi dan sangat detail, oleh karena itu dengan menggunakan teknik modifikasi dan stilasi akan mereduksi tingkat kerumitan pembuatan desain tanpa mengurangi akurasi informasi identitas objeknya. Strategi pembentukan modul desain diawali dengan menetapkan bagian-bagian utama dari objek sebagai "jangkar bentuk" untuk menjadi identitasnya. Penentuan bagian-bagian tersebut bertujuan agar identitas objek akan tetap terbaca meskipun sudah mengalami proses stilasi. Selain itu tindakan modifikasi dilakukan pula terhadap elemen-elemen pelengkap desain yang akan menjadi pembentuk struktur objek, dan akan dibuat dalam bentuk clip art. Clip art-clip art tersebut memiliki fungsi sebagai penyempurna bentuk modul sehingga tercipta modul ragam hias yang utuh.
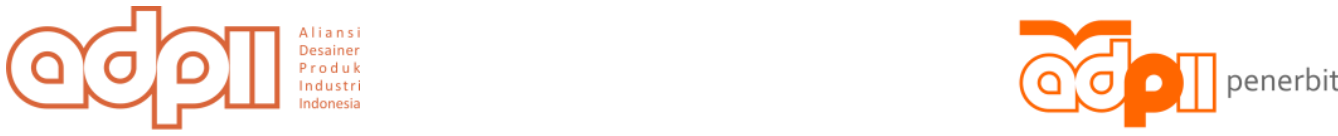
Penggunaan teknologi digital telah memungkinkan komponen clip art dapat dimodifikasi dan didokumentasi dengan cepat dan bervariasi untuk kemudian disimpan dalam bentuk clip art library sehingga dapat "dipanggil" dan digunakan kembali pada saat pembuatan modul lainnya.

Penggunaan teknologi digital yang digunakan untuk mengembangkan gagasan-gagasan desain tersebut juga memberikan peluang aplikasi produksi pada beberapa mesin produksi yang berbasis pada sistem digital dan computerized yang pada saat ini sudah mulai banyak ditemukan di tengah masyarakat. Objekobjek digital seperti ragam hias burung elang di atas dapat dikonversi dan dieksekusi menggunakan mesin digital printing, computerized embriodery machine, laser cutting/ engraving machine, bahkan mesin pemodelan $3 D$ printing.

\section{KESIMPULAN}

Pembuatan modul desain ragam hias melalui Teknik Modifikasi Digital (Digital Modification Techniques/DMT) merupakan metode pengembangan kreasi yang dinilai cukup mudah dipelajari dan efektif untuk meningkatkan produtivitas IKM dalam menghasilkan desain-desain baru. Teknik tersebut mampu menghadirkan unsur-unsur kebaruan bentuk dengan operasi sederhana melalui bantuan software aplikasi yang populer digunakan dalam dunia desain. Teknik kreasi tersebut dapat mereduksi hambatan-hambatan utama yang dihadapi para tenaga desain di IKM, yaitu keterampilan memvisualisasikan gagasan dan kepekaan estetik terhadap suatu bentuk. Kedua hambatan tersebut banyak ditemukan di industri-industri yang berbasis produksi seperti umumnya industri kecil di Indonesia, sehingga metode pengembangan kreasi ini menjadi sangat penting agar dapat mereduksi hambatan-hambatan seperti itu dan mampu mendorong peningkatan produktivitas industri dalam hal mengembangkan desain yang dihasilkannya.

Pada metode kreasi yang dikembangkan ini, objek desain berupa motif ragam hias dibuat melalui penyusunan struktur dan komposisi elemen-elemennya yang terdiri dari elemen utama sebagai "jangkar bentuk" dan elemen-elemen pendukung sebagai penyempurnanya. Pembuatan dan penyusunan modul ragam hias ini menggunakan software aplikasi desain sehingga pembuatannya menjadi lebih cepat dipelajari dan digunakan oleh para tenaga kerja desain yang umumnya tidak terdidik tersebut.

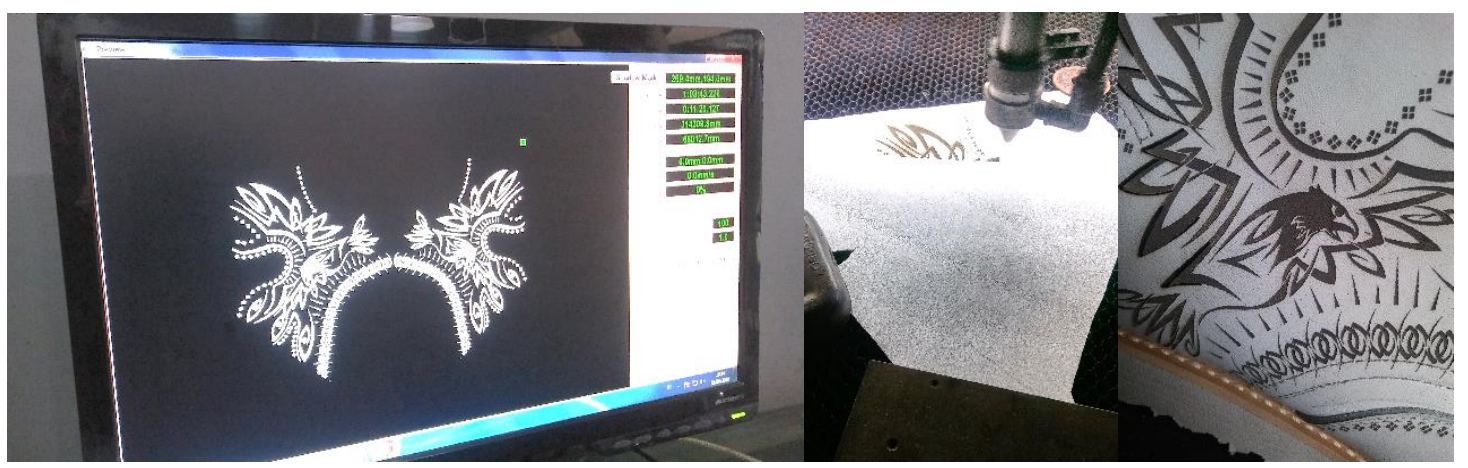

Gambar 5. Proses eksekusi desain modul ragam hias digital menggunakan teknologi laser cutting/ engraving

Sumber Gbr: Dokumen pribadi

Penggunaan teknologi digital sangat memungkinkan untuk dieksekusi pada mesin-mesin produksi yang dilengkapi perangkat komputer (computerized machine) yang pada saat ini sudah mulai banyak digunakan dan mudah untuk ditemukan di tengah-tengah masyarakat. Oleh karena itu kesiapan IKM dalam mengembangkan kreasi dan kesiapan perangkat produksi yang sudah memiliki kecepatan dan akurasi tinggi tersebut diharapkan mampu menghasilkan produk-produk yang memiliki keunggulan desain untuk bersaing dengan produk-produk sejenis di tengah pasar bebas seperti yang ada saat ini.

\section{TERIMA KASIH}

Terima kasih kepada Kementerian Riset dan Pendidikan Tinggi RI yang telah mendukung pembiayaan pelaksanaan kegiatan penelitian ini. Kepada Institut Teknologi Nasional, para nara sumber, responden, penyedia fasilitas pengkajian yang juga telah memberikan dukungan data dan fasilitas sehingga penelitian ini dapat diselesaikan sesuai dengan harapannya. Semoga hasil penelitian berupa strategi
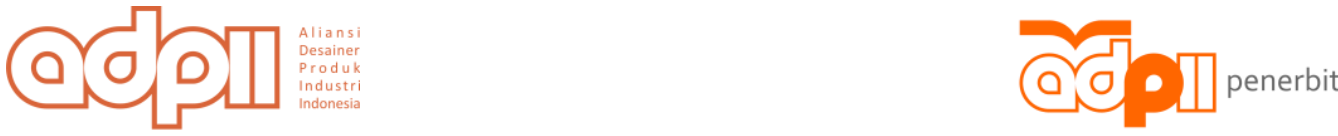
praktis untuk meningkatkan kemampuan kreasi para pekerja desain di IKM alas kaki ini dapat bermanfaat dan turut membantu meningkatkan produktivitas mereka.

\section{DAFTAR PUSTAKA}

[1] K. "SIARAN PERS: Kementerian Perindustrian RI," 03 August 2018. [Online]. Available: http://www.kemenperin.go.id/artikel/17565/Empat-Strategi-Indonesia-Masuk-Revolusi-IndustriKeempat.

[2] A. D. Tohjiwa, "PENGARUH PENERAPAN TEKNOLOGI TERHADAP PERUBAHAN STRUKTUR MASYARAKAT INDONESIA," 19 Agustus 2018. [Online]. Available: http://agus_dh.staff.gunadarma.ac.id/.

[3] D. Lesmana, “autotekno.sindonews.com," 9 April 2016. [Online]. Available: https://autotekno.sindonews.com/read/1099696/133/pentingnya-teknologi-digital-untuk-paraukm-1460210674.

[4] Gamadaz, “Gamadaz," 20 Agustus 2018. [Online]. Available: https://gamadaz.com/peran-teknologidalam-bidang-arsitektur-dan-desain-interior/.

[5] V. Velev, "DIGITAL CREATIVITY: ADVANTAGES, PROBLEMS, RESPONSIBILITIES," International Journal "Information Theories \& Applications" Vol.11, p. 60, 2004.

[6] N. Bonnardel dan F. Zenasni, "The Impact of Technology on Creativity in Design: An Enhancement?," CREATIVITY AND INNOVATION MANAGEMENT, p. 180, 2010.

[7] K. Kudiya, Interviewee, Strategi Pengembangan Ragam Hias di Batik Komar. [Wawancara]. 17 September 2017.

[8] D. Handoko, Kriminalisasi dan Dekriminalisasi Dibidang Hak Cipta, Pekanbaru: Hawa dan Ahwa, 2015, p. 205.

[9] Cahbagoes, "Sejarah Batik Mega Mendung dan Penjelasannya," 07 September 2018. [Online]. Available: https://batik-tulis.com/blog/batik-mega-mendung/.

[10] Redaksi, “Komunitas Pelestari Batik Tulis," 15 April 2017. [Online]. Available: http://batik.or.id/sejarah-batik-cirebon-dan-penjelasannya/.

[11] P. Prayitno, “Liputan 6," 2 Oktober 2016. [Online]. Available: https://www.liputan6.com/regional/read/2616134/makna-tersembunyi-di-balik-batik-megamendung-cirebon.

[12] M. A. Waskito, "PENERAPAN TEKNIK STILASI PADA MOTIF RAGAM HIAS SEBAGAI METODE PENINGKATAN KEMAMPUAN KREATIF PELAKU USAHA IKM ALAS KAKI," LP2M ITENAS, Bandung, 2017.

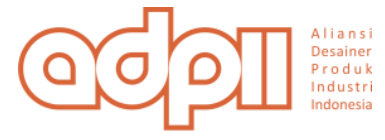

